\title{
Editorial
}

\section{Dossiê Avaliação da Aprendizagem}

n. 55 , out./dez. 2020

José Eustáquio Romão

Editor

Diretor do Programa de Pós-graduação em Educação

(PPGE-UNINOVE)

Universidade Nove de Julho (UNINOVE)

(iD) Maurício Pedro da Silva

Editor

Universidade Nove de Julho (UNINOVE)

Para citar - (ABNT NBR 6023:2018)

ROMÃO, José Eustáquio; SILVA, Maurício Pedro da. Editorial. Eccos - Revista Cientifica, São Paulo, n. 55, p. 1-3, e18868, out./dez. 2020. Disponível em: https://doi.org/10.5585/eccos.n55.18868.

Iniciando uma nova fase em sua vida editorial, a revista $E c c o S$ passa a publicar dossiês cujos artigos serão encomendados a especialistas na temática objeto do dossiê e, apenas excepcionalmente, poderá captar e a eles agregar os artigos submetidos à chamada "demanda espontânea", quando aderentes à mencionada temática e quando portadores de uma qualidade referencial.

A escolha da temática de um dossiê obedecerá, a partir deste número, à emergência de uma problemática contemporânea e de interesse amplo e que ultrapasse até mesmo as fronteiras nacionais. Assim, por exemplo, o dossiê deste número, composto por 4 (quatro) artigos, foi encomendado a especialistas em avaliação da aprendizagem.

O tema da avaliação tornou-se consensualmente recorrente no Brasil e no mundo, nas três últimas décadas, a despeito da diversidade de correntes de pensamento que o abordam, evidenciando concepções e interesses diferentes e até mesmo conflitantes. Não há como negar, na atualidade, a importância de um tema tão recorrente nos eventos da área de educação, nos cursos de formação docente e na produção bibliográfica nacional e mundial. De fato, a avaliação, nas suas três modalidades - da aprendizagem, de desempenho e institucional -, estabeleceu-se definitivamente no campo da educação, para o bem e para o mal. Não há país do 
mundo que não tenha criado seus organismos responsáveis pelos "exames nacionais", transformando a avaliação, até então ausente do campo da educação, em tema da moda, haja vista a parca literatura sobre ele antes dos anos 80 do século passado e sua abundância a partir da segunda metade da mesma década.

Há muito que temos indagado sobre quem faz a moda em educação e com que intenção. As respostas não são fáceis, pois embora os organismos educacionais, da UNESCO à mais humilde secretaria municipal de educação, a tenham abraçado incondicionalmente, não foram eles que a tornaram central nas pautas e nas agendas educacionais. Esse protagonismo coube às agências multilaterais que tratam de assuntos econômicos, como o Banco Mundial e a Organização para a Cooperação e o Desenvolvimento Econômico (OCDE). Como se tornou jargão no meio dos pesquisadores do tema, essas agências são, hoje, os think tanks da avaliação educacional. Ora, esta importância dada por organismos de tal natureza e com uma cobertura planetária evidencia que a educação não pode ser considerada como de "baixa intensidade" nos fenômenos da globalização e nas teorias do "globalismo", como quer Boaventura de Souza Santos e seus seguidores ${ }^{1}$. Em suma, o tema da avaliação educacional será sempre mais do que oportuno nos estudos, pesquisas, discussões e publicações da área de educação.

Neste número, os artigos que compõem o dossiê brindam-nos com as seguintes discussões:

a) análise dos impactos da pandemia do Covid 19 nos processos de avaliação da aprendizagem nos cursos de graduação;

b) práticas de avaliação da aprendizagem na concepção dos alunos do curso de administração da Universidade Estadual do Paraná;

c) avaliação em cursos superiores de artes, destacando-se a educação pelo sensível, na formação de professores para a Educação Básica e

d) formação de professores e avaliação da aprendizagem na universidade, com ênfase na metodologia da Pesquisa-Ação.

Além dessas atualíssimas reflexões proporcionadas pelo dossiê, este número da $E c c o S$ oferece, ao leitor, uma diversidade temática e referencial presente nos artigos que se submeteram aos editais anteriores, tendo passado por rigorosos "filtros" dos critérios da revista e do talento da plêiade de pareceristas que têm trabalhado, intensamente, nos mais de 200

\footnotetext{
${ }^{1}$ Boaventura de Souza Santos coordenou um grande projeto, por intermédio do Centro de Estudos Sociais (CES) da Universidade de Coimbra, de que resultou a Coleção "A Sociedade Portuguesa Perante os Desafios da Globalização: Modernização Económica, Social e Cultural", em 8 volumes. Nela, especialmente no volume 6, Transnacionalização da educação: da crise da educação à "educação da crise", organizado por Stephen R. Stoer, Luíza Cortesão e José A. Correia (Porto: Afrontamento, 2001), fica evidenciada esta afirmação sobre a baixa intensidade da educação na tipologia das "taxas de globalização".
} 
artigos que estavam acumulados no site do periódico. Aliás, como é óbvio, o grande número de submissões permitiu uma melhor seleção de artigos altamente qualificados.

Certamente, quando a submissão de artigos for novamente aberta, ela buscará captar trabalhos de todo o país e do exterior, como vem tradicionalmente fazendo, para compor o restante da revista. Observe-se que, neste número 55, há artigos de todas as regiões do Brasil e de instituições de educação superior (IES) das diferentes redes (federal, estadual, municipal e particular).

Ainda que oriundos exclusivamente de instituições universitárias, numa clara demonstração da vitalidade da pesquisa e da produção científica e tecnológica da academia brasileira, os artigos que compõem este número exprimem o prestígio deste periódico na comunidade acadêmica nacional. Se se lembrar que o edital para a captação de artigos está temporariamente fechado, pelo excesso de trabalhos já submetidos e em tramitação (cerca de 60 em avaliação e mais de 80 em edição), este prestígio se torna exponencial, na medida em que os pesquisadores e as pesquisadores somente buscam um veículo de divulgação quando confiam em sua qualidade gráfica, no rigor de sua seleção dos trabalhos submetidos e no oferecimento do máximo de pontuações nas avaliações dos órgãos reguladores.

Para este número, foram selecionados 13 (treze) artigos da demanda espontânea, e os critérios de seleção continuaram os mesmos: excelência temática e /ou referencial dos trabalhos submetidos, além da tentativa de cobertura regional, para identificar e estabelecer uma espécie de relativo "estado da arte" da pesquisa educacional atual em todo o território nacional. 